\title{
THE EFFECTS OF CUTTING CONDITIONS ON THE CUTTING TORQUE AND TOOL LIFE IN THE TAPPING PROCESS FOR AISI 304 STAINLESS STEEL
}

\author{
VPLIV POGOJEV REZANJA NA MOMENT PRI REZANJU IN \\ ZDRŽLJIVOST NAVOJNEGA VREZNIKA PRI VREZOVANJU \\ NOTRANJIH NAVOJEV V NERJAVNO JEKLO AISI 304 \\ Gultekin Uzun, Ihsan Korkut \\ Gazi University, Faculty of Technology, Manufacturing Engineering, Ankara, Turkey \\ uzun.gultekin@gazi.edu.tr \\ Prejem rokopisa - received: 2015-02-22; sprejem za objavo - accepted for publication: 2015-04-09
}

doi: $10.17222 /$ mit.2015.044

\begin{abstract}
In this study tapping operations were carried out using taps of different diameters and with different cutting parameters on AISI 304 austenitic stainless steel. The cutting performances of the taps were determined according to the cutting torques created during the threading and the depth of cut for each cutting feed $(Q)$. With the aid of the obtained experimental data the solution suggestions to the problems in the threading operations for AISI 304 steel were developed. As a result it was specified that the increasing amount of cutting in each pass directly affected the cutting torque. It was determined that there was a tendency to decrease the cutting torque with the increasing depth of cut for each cutting feed. The best tool-life results for an M5 tap were obtained at a 5-mm $Q$ value, whereas for M6 taps it was at a 3-mm $Q$ value.

Keywords: tapping, AISI 304, machinability
\end{abstract}

V študiji je bilo izvedeno vrezovanje notranjih navojev $\mathrm{z}$ uporabo navojnega vreznika $\mathrm{z}$ različnimi premeri in različnimi nivoji vrezovalnih parametrov v avstenitnem jeklu AISI 304. Zmogljivosti vrezovanja navojnih vreznikov so bile določene glede na moment, ki je nastal med vrezovanjem navojev v globino, za vsako hitrost podajanja pri vrezovanju $(Q)$. S pomočjo dobljenih eksperimentalnih podatkov so bili postavljeni predlogi rešitev problemov pri postopku vrezovanja navojev pri jeklu AISI 304 Pokazalo se je, da povečanje vrezovanja pri vsakem prehodu neposredno vpliva na moment pri vrezovanju. Ugotovljeno je, da se zmanjšuje moment vrezovanja s povečanjem globine reza pri vsakem podajanju pri vrezovanju. Najboljša zdržljivost orodja pri M5 vrezniku je bila dosežena pri vrednosti $Q=5 \mathrm{~mm}$, pri vrezniku M6 pa pri vrednosti $Q=3 \mathrm{~mm}$.

Ključne besede: vrezovanje notranjih navojev, AISI 304, strojna obdelava

\section{INTRODUCTION}

The need for stainless steels in industry is increasing day by day along with technological developments. Several types of stainless steels are used, especially in the manufacturing of the storage tanks, pressure vessels, heat exchangers and stainless pipes used in the petrochemistry, chemistry and food industries. One of the ways of increasing the strength of stainless steel is to increase the content of the main alloying elements, such as chrome and nickel, and to decrease the carbon content. In recent years, rapid improvements in technology have led to an increase in the expectations from the new methods used in the manufacturing of materials. ${ }^{1,2}$

The high tensile strength of stainless steels is the main cause of their poor machinability. The distance between the yield and rupture points of stainless steels is more than that of normal carbon steels. Therefore, a higher cutting force is needed for the machining of stainless steels compared to normal carbon steels. The poor machinability of austenitic stainless steels stems from their low heat conductivity and high work-hardening properties. ${ }^{3}$ In the turning operations of AISI 304 and AISI 316 austenitic stainless steels, TiC/TiCN/TiN- coated cutting tools lead to lower cutting forces than those for $\mathrm{TiC} / \mathrm{TiCN} / \mathrm{Al}_{2} \mathrm{O}_{3}$-coated cutting tools. In a study in the literature, it was specified that the cutting speed did not cause any significant change in the cutting forces, while it affected the surface roughness significantly. ${ }^{4}$ In the turning process for AISI 304 stainless steel, at high cutting speeds exceeding the $150 \mathrm{~m} / \mathrm{min}$, the tool wear and the surface-roughness values were decreased with the increasing of the cutting speed. ${ }^{5}$

The cutting tools should provide the suitable cutting parameters required for maximum efficiency. In the threading process, the selection of the correct tap and the necessary parameters (feed, revolution, cooling liquid etc.) are of importance in terms of the threading quality and the economy of production. Incorrect tap selection causes increased costs and time loss. In Germany, in the machine manufacturing industry, the total time spent for threading is equal to $22 \%$ of the total machining time. ${ }^{6}$

The operation steps between the cutting tool and the material during tapping are complicated compared to other cutting tools. The selection of the correct tap and the cutting conditions is a necessity for the efficient use of the tap. In a study, it was emphasized that higher 
Table 1: Chemical composition of AISI 304 austenitic stainless steel ${ }^{14}$

Tabela 1: Kemijska sestava avstenitnega nerjavnega jekla AISI $304^{14}$

\begin{tabular}{|c|c|c|c|c|c|c|c|}
\hline \multicolumn{9}{|c|}{ Chemical composition } & $\mathrm{S}$ & $\mathrm{Cr}$ & $\mathrm{Ni}$ & $\mathrm{N}$ \\
\hline $\mathrm{C}$ & $\mathrm{Mn}$ & $\mathrm{Si}$ & $\mathrm{P} \max$ & $\leq 0.015 \%$ & $17.50-19.50 \%$ & $8.00-10.50 \%$ & $\leq 0.11$ \\
\hline
\end{tabular}

forces occurred on the coatings having a lower wear resistance, in contrast with the higher wear-resistant coatings. In the tapping, the TiCN-coated taps exhibited excellent abrasive and adhesive wear resistances. ${ }^{7}$ It was specified that during the tapping of deep holes with small-diameter taps, the reason for frequent tool breakage was the higher torque during threading. ${ }^{8}$ The lowest cutting torque in the tapping operations was obtained under dry-cutting conditions. ${ }^{9}$ It was stated that the cutting liquids containing fluorine formed a lubricant film layer between the tool and workpiece interface, which led to an increase in tool life by preventing build-upedge formation on the tool and thus the cutting forces could be decreased by about $18 \% .^{10}$ The thread precision of $\mathrm{CBN}$-coated taps exhibited improvements in the tapping torque and tool life. The tool life and tapping-torque resistances of $\mathrm{CBN}$-coated taps provided better results compared to conventionally coated taps. ${ }^{11}$ In some studies, estimation models were also developed to predict the torque occurring during the tapping. ${ }^{9-13}$

As can be seen from the literature, the tapping of AISI 304 stainless steel is a difficult process owing to its poor machinability. Tapping is a complicated operation and this makes it difficult to solve the problems in this field. There have been limited studies carried out to determine cutting torque, tool life and tool wear regarding the tapping processes.

\section{MATERIALS AND METHOD}

Tapping a deep hole in the rigid tapping mode may be difficult due to chip sticking on the tool. In such cases, the peck rigid tapping cycle is useful. In this study, the peck rigid tapping operation was carried out using the Tapping cycle (G84). The chip breaking command of

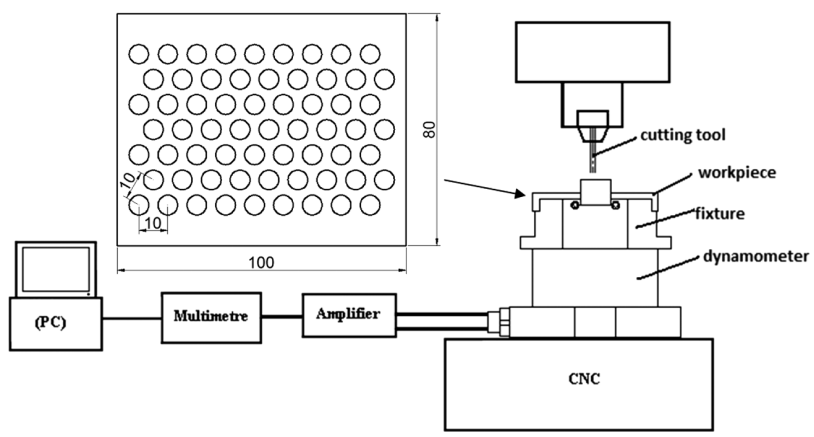

Figure 1: Drawings of the samples used in the tests and the experimental setup

Slika 1: Risba vzorcev, uporabljenih pri preizkusu in eksperimentalni sestav
G83 and the depth of cut for each cutting feed $(Q)$ in each pass are entered into G84 and in this way the cutting tool can break the chip during the tapping operation. The sample program used is given as follows:

G84 X25. Y25. Z-20. R5. Q5. F203.64 S255.

At the end:

- The effect of different cutting parameters on the cutting torque,

- The effect of the addition of the $Q$ value to the G84 command on the cutting torque,

- The effects of $Q$ values added to the G84 command on the tool life were determined.

- The materials and equipment that are used in the tests are listed below.

\subsection{Experimental method}

The chemical composition of the AISI 304 austenitic stainless steel used in the tests is given in Table 1. ${ }^{14}$

The test samples were prepared as prismatic plates with a size of $100 \mathrm{~mm} \times 80 \mathrm{~mm} \times 15 \mathrm{~mm}$. A mold was designed to fix the test samples to the dynamometer. In the tapping tests, 63 holes were drilled in each sample. The distribution of holes on the upper surface of the samples is given in Figure 1. By taking into consideration the hardness distribution around the drilled hole, the symmetrical placing of holes on the piece was done carefully.

The cutting forces and moments were measured using a KISTLER 9272 A type dynamometer. The dynamometer was fixed to the vertical machining center and thus the three cutting forces $\left(F_{x}, F_{y}, F_{z}\right)$ and the moment $\left(M_{z}\right)$ could be measured simultaneously. A fixing die and a workpiece were placed on the dynamometer to perform the cutting tests properly. In the designed system, the force data is taken from the workpiece by direct contact between the workpiece and the dynamometer (Figure 1).

The tap types and forms are given in the technical data in Figure 2.

Drills with diameters of $\varnothing 4.2$ and $\varnothing 5.0 \mathrm{~mm}$ were used for the drilling of the tapping holes. In the tests, for the purpose of preventing the taps experiencing excessive cutting torques, a tapping cap and a safety tap holder were used.

The wear and material adhesions on the cutting tools were examined by using an AM413ZT Polarized Digital Microscope at $50 \times$ magnification (Figure 3).

In this study, four different cutting speeds (4-6-8-10 $\mathrm{m} / \mathrm{min})$ and four different $Q(3-5-8-20 \mathrm{~mm})$ values were used to determine the suitable cutting parameters under 


\begin{tabular}{|c|c|c|c|c|c|}
\hline Tap & $\begin{array}{c}\text { Tap shape } \\
\text { (Form DIN } \\
371)\end{array}$ & Mouth type & $\begin{array}{c}\text { Helical } \\
\text { channel }\end{array}$ & Material & $\begin{array}{c}\text { Drill } \\
\text { diameter } \\
(\mathrm{mm})\end{array}$ \\
\hline $\mathrm{M} 5 \times 0.8$ & $\begin{array}{c}\text { Form B } \\
(3.5-5 \text { Thread }\end{array}$ & Oblique & Flat & $\begin{array}{c}\text { HSS-E } \\
\text { (Normal) }\end{array}$ & 4.2 \\
\hline $\mathrm{M} 6 \times 1.0$ & $\begin{array}{c}\text { Form B } \\
(3.5-5 \text { Thread })\end{array}$ & Oblique & Flat & $\begin{array}{c}\text { HSS-E } \\
\text { (Normal) }\end{array}$ & 5.0 \\
\hline Tap & $l_{1}$ (mm) & $l_{2}$ (mm) & $d_{2} \varnothing(\mathrm{mm})$ & $a(\mathrm{~mm})$ & $l_{3}(\mathrm{~mm})$ \\
\hline $\mathrm{M} 5 \times 0.8$ & 70 & 13 & 6 & 4.9 & 8 \\
\hline $\mathrm{M} 6 \times 1.0$ & 80 & 15 & 6 & 4.9 & 8 \\
\hline
\end{tabular}

Figure 2: Technical data of M5 and M6 taps

Slika 2: Tehnični podatki za M5 in M6 navojne svedre

dry-cutting conditions. Taps with different diameters were used to evaluate in detail the effects of the cutting parameters mentioned above on the tapping process. By considering these parameters and studies in the literature, appropriate values in the cutting-tool catalogs were taken into consideration.

\subsection{Tapping and measurement of the cutting torque}

In the tapping process, a rotating torque (cutting torque) is produced. The most effective factor in the tapping process is rotation torque (Figure 4). There are some factors affecting this, i.e., chip angle, chamfer length, tap form, work piece material, cutting liquid, etc. A wider chip angle decreases the cutting torque, but at the same time decreases the strength of the tap. The main purpose of using the cutting liquid (emulsion, cutting oil, etc.) during tapping is to decrease the friction between the cutting tool and the workpiece. One of the main reasons for heating and cutting torques as a result of friction is the chip squeezing in the tap channels. To prevent this chip squeezing, an appropriate tap form must be selected in accordance with the workpiece and hole type, and in this way the chip in the tap channels is

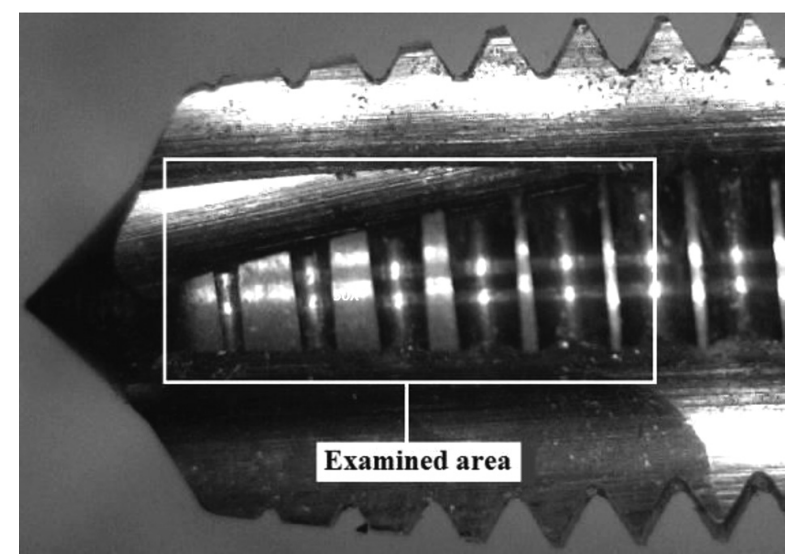

Figure 3: Examined zones of the cutting tools through a digital microscope

Slika 3: Preiskovana področja rezalnega orodja, prikazana z digitalnim mikroskopom

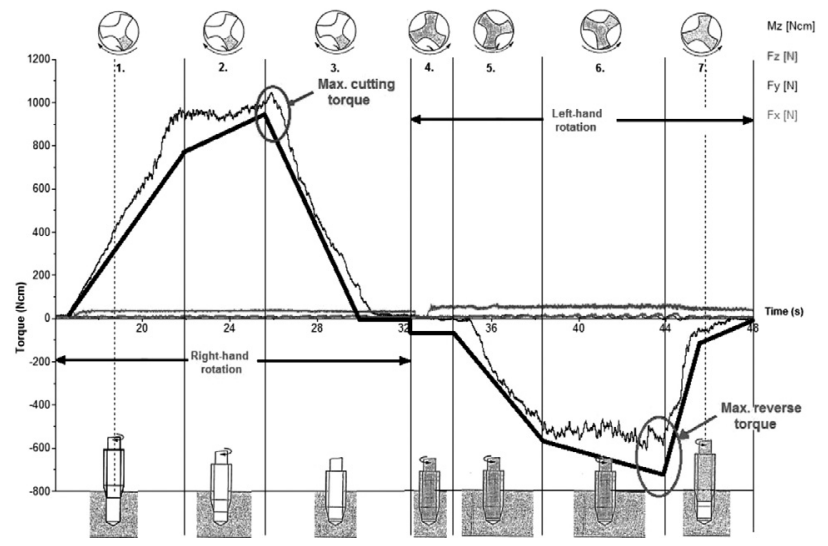

Figure 4: Graphical and experimental measurement of the cutting torque during tapping ${ }^{16}$

Slika 4: Grafični prikaz eksperimentalnih meritev momenta pri vrezovanju notranjih navojev ${ }^{16}$

removed. In Figure 4, during the tapping process, graphical and experimental measurements of the torque are shown:

1. zone) beginning of cut to full contact of all chamfer teeth,

2. zone) cutting torque of the tap that is now cutting with all its chamfer teeth,

3. zone) breaking the machine spindle to a stop,

4. zone) bBeginning reversal of the spindle to contact of the tooth back with the chip root left standing by the next cutting tap tooth,

5. zone) shearing off the chip root,

6. zone) squashing back the chip root remains in place after the shearing off of the chip root (size depending on the chamfer relief angle of the tap and on the rear cutting angle of the tap tooth),

7. zone) sliding friction between tap and workpiece.

\section{RESULTS AND DISCUSSION}

In this study, the type of tap and cutting parameters were considered as the input, whereas cutting torque (moment) $\left(M_{z}\right)$, which is very important among the cutting forces, was considered as the output. The change of cutting torque (depending on the $Q$ values) that is created during threading under dry-cutting conditions at different cutting speeds with the M5 tap is given in Figure 5 .

From Figure 5 it is clear that the increase in the values of $Q$ led to a decrease in the cutting torque. The highest cutting-torque values for all cutting speeds were measured for the $Q$ value of $3 \mathrm{~mm}$. The reason for this is the formation of a discontinuous cutting operation and the insufficient heat in the cutting area for the deformation of the material. ${ }^{3}$ The second largest cutting-torque values were obtained for the $Q$ value of $5 \mathrm{~mm}$. For the $Q$ value of $8 \mathrm{~mm}, 4 \%$ and $8 \%$ increases were calculated for the $8 \mathrm{~m} / \mathrm{min}$ and $10 \mathrm{~m} / \mathrm{min}$ cutting speeds compared to the $Q$ value of $5 \mathrm{~mm}$. At the cutting speeds of $4 \mathrm{~m} / \mathrm{min}$ 


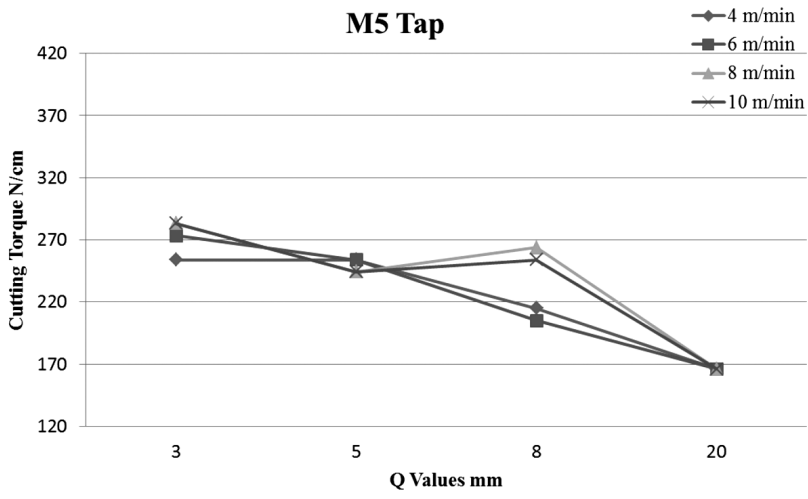

Figure 5: Change of cutting torque (depending on the $Q$ values) at different cutting speeds with the M5 tap

Slika 5: Spreminjanje momenta pri vrezovanju (odvisno od vrednosti $Q)$ pri različnih hitrostih rezanja z navojnim svedrom M5

and $6 \mathrm{~m} / \mathrm{min}$, the cutting torque decreased in comparison to that of the $Q$ value of $5 \mathrm{~mm}$. The lowest cutting-torque values were obtained by increasing the $Q$ value to $20 \mathrm{~mm}$. This was attributed to the formation of sufficient heat for cutting in the cutting area due to the lower heat conductivity of the AISI 304 material..$^{5,15}$ The continuous cutting operation provided an easier chip removal. The angular slope at the cutting mouth makes the chip removal easier. In this way, there is no chip accumulation and the tap can make the cutting operation easy. The number of chamfers is 4-5 threads and this decreases the moment distributed to the threads, ending up with a lower cutting moment. ${ }^{9,16,17}$

The change of cutting torque depending on the $Q$ values that emerged during threading under dry-cutting conditions at different cutting speeds with the M6 tap is given in Figure 6.

For the M6 tap from Figure 6 it is clear that the increase in the values of $Q$ caused a decrease in the cutting torque. When changing the $Q$ values from $3 \mathrm{~mm}$ to $5 \mathrm{~mm}$ an increase was observed, after which the tendency to decrease continued. The highest cutting-torque values were obtained with a $Q$ value of $5 \mathrm{~mm}$. The reason for this was attributed to an inappropriate cutting speed/feed

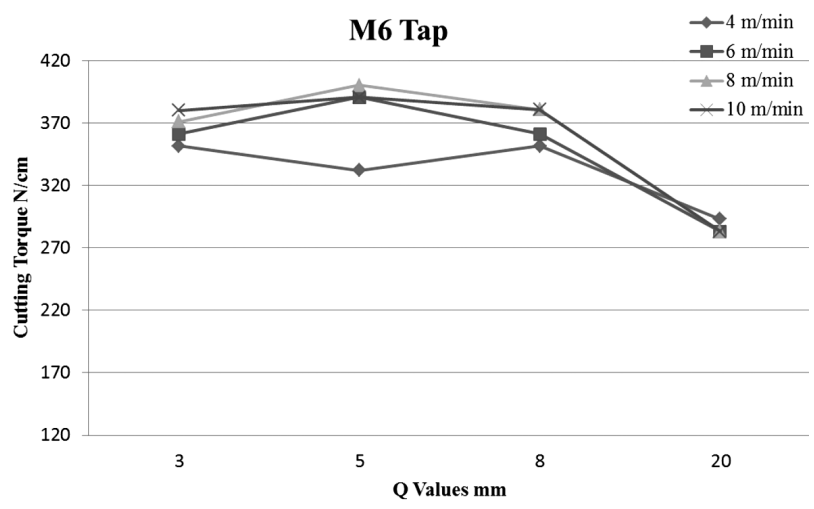

Figure 6: Change of cutting torque (depending on the $Q$ values) at different cutting speeds with the M6 tap

Slika 6: Spreminjanje momenta pri vrezovanju (odvisno od vrednosti $Q)$, pri različnih hitrostih rezanja z navojnim svedrom M6 ratio. In addition, the discontinuous formation of the cutting operation caused insufficient heat for the material deformation. ${ }^{11}$ The second highest cutting-torque values were seen for the $Q$ values of $3 \mathrm{~mm}$ and $8 \mathrm{~mm}$. When $Q$ was $20 \mathrm{~mm}$ the lowest cutting-torque values were obtained. This was explained by the formation of sufficient heat for cutting in the cutting area due to the lower heat conductivity of the AISI 304 material. ${ }^{3,5,15}$ The angular slope at the mouth of the cutting tool and the continuous cutting operation made the chip removal easier. Thus, the tap worked easily and there was no chip pile-up. The chamfer of the tap along with 4-5 threads led to a decrease in the moment, which was distributed to the threads and caused the cutting moment to have lower values. ${ }^{18,19}$

Tool-life tests were carried out at an $8 \mathrm{~m} / \mathrm{min}$ cutting speed (average speed). Graphics were drawn by calculating the distance of the cutting tool as the cutting-tool life. The distance of the cutting tool was calculated by multiplying the workpiece thickness by the number of threaded holes. Tapping processes were repeated until the breaking of each cutting tool and obtaining the excessive chip build-up-edge.

Figure 7 shows that in the tool-life tests with the M5 tap the shortest tool life came out to be $60 \mathrm{~mm}$ at the lowest and highest $Q$ values. The best tool life was determined to be $200 \mathrm{~mm}$ for the $5 \mathrm{~mm} Q$ value. When the cutting-tool life for the M5 tap is examined, it is seen that the tool life decreases with an increasing $Q$ value.

As seen from Figure 8 the chip build-up-edge values on the cutting tools are the most important factor affecting the tool life. ${ }^{11,13,18}$ In stainless steels, higher ductility makes the machinability difficult. In tapping, the material build-up-edge to the cutting mouths causes squeezing. As a result of these squeezes there are breakages in the cutting tools (Figure 8d).

When Figure 7 is examined for the M6 tap, the effect of $Q$ value is clearly seen. The longest tool life for a $3 \mathrm{~mm} Q$ value was $255 \mathrm{~mm}$. The tool life decreased with

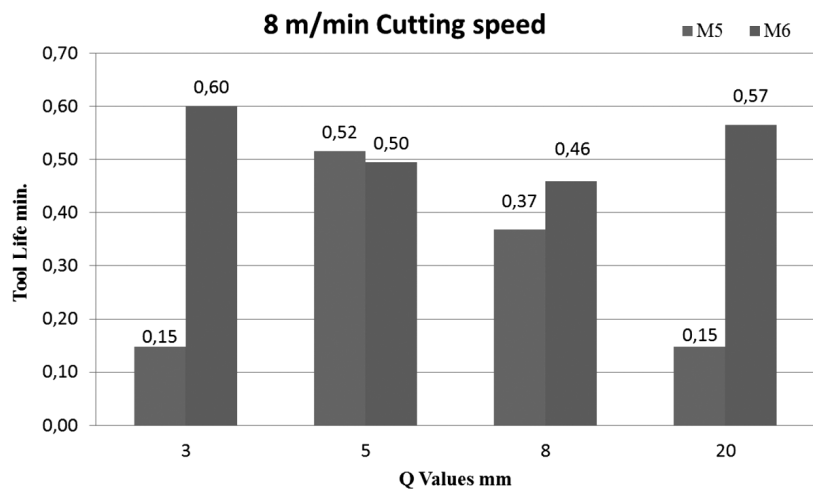

Figure 7: Change of tool life for M5 and M6 taps depending on the $Q$ values

Slika 7: Spreminjanje zdržljivosti M5 in M6 navojnega svedra v odvisnosti od vrednosti $Q$ 

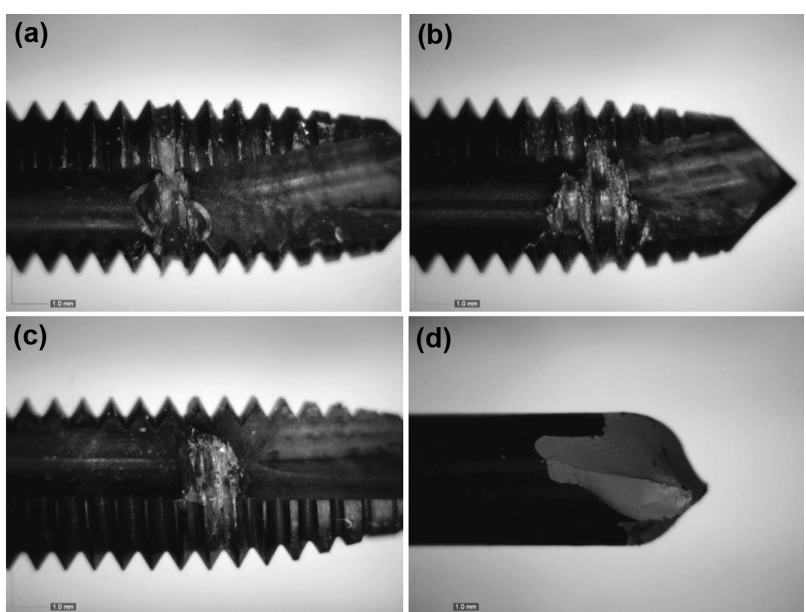

Figure 8: Tool-life (distance of cutting tool) images for M5 at $8 \mathrm{~m} / \mathrm{min}$ cutting speed, depending on the $Q$ values of: a) $3 \mathrm{~mm}$, b) 5 $\mathrm{mm}$, c) $8 \mathrm{~mm}$, d) $20 \mathrm{~mm}$

Slika 8: Posnetki zdržljivosti orodij (razdalja rezanja orodja) za M5, pri hitrosti rezanja $8 \mathrm{~m} / \mathrm{min}$, v odvisnosti od vrednosti $Q$ : a) $3 \mathrm{~mm}$, b) $5 \mathrm{~mm}$, c) $8 \mathrm{~mm}$, d) $20 \mathrm{~mm}$

an increasing $Q$ value. The second best tool life (240 $\mathrm{mm}$ ) was obtained for a $20 \mathrm{~mm} Q$ value.

From Figure 9 it is clear that all of the cutting tools were broken due to tool squeezing. The main reason for the breaking of the tools was the build-up-edge of the chip. The ductile structure of the AISI 304 material provides the build-up-edge formation at the cutting mouths of the taps. The filling of cutting mouths makes the cutting operation difficult and causes breakage of the cutting tool. ${ }^{11,13}$

When Figure 7 was examined for the M5 and M6 taps, it was seen that the best tool-life results were obtained with the M6 taps. The effect of $Q$ value was seen clearly for both the cutting tools. The best tool-life results for the M5 tap were obtained for a $5 \mathrm{~mm} Q$ value, and for a $3 \mathrm{~mm} Q$ with M6. The best results from the point of view of cutting torques were not obtained at these values mentioned above, but this did not affect the tool life significantly. As a result, in threading with small-scale taps under suitable conditions, it can be said that the $Q$ value can be used.

\section{CONCLUSION}

The results obtained from this study are summarized as below:

- The cutting-torque values for each of the depth of cut and cutting feed $(Q)$ values have been determined. This was the case for both cutters. A high cutting torque was obtained with the lowest and highest $Q$ values.

- The most important factor affecting the tool life was the build-up-edge formation on the tools. In the tapping operation, the build-up-edge chips on the cutting mouths caused squeezing, which resulted in breakages of the cutting tools.
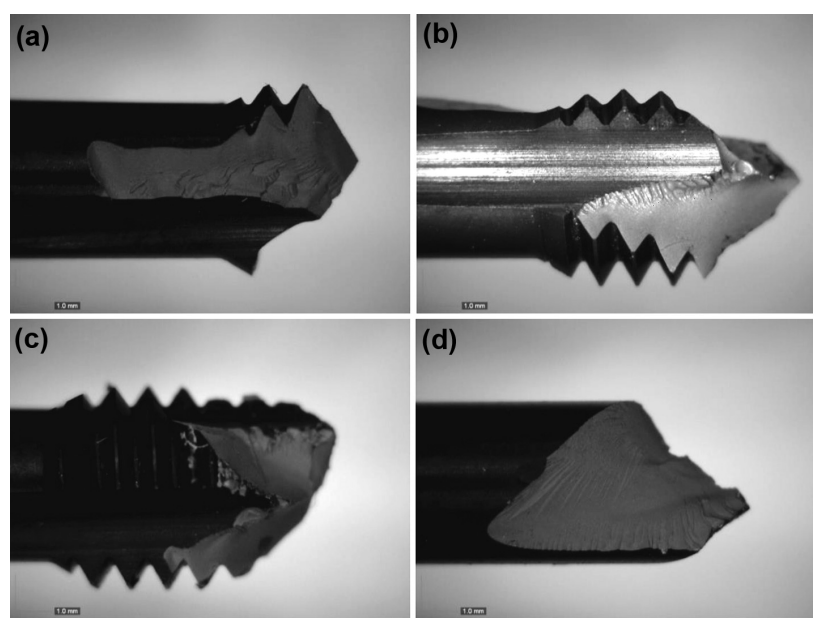

Figure 9: Tool-life (distance of cutting tool) images for M6 at $8 \mathrm{~m} / \mathrm{min}$ cutting speed, depending on the $Q$ values of: a) $3 \mathrm{~mm}$, b) $5 \mathrm{~mm}$, c) $8 \mathrm{~mm}$, d) $20 \mathrm{~mm}$

Slika 9: Posnetki zdržljivosti orodij (razdalja rezanja orodja) za M6, pri hitrosti rezanja $8 \mathrm{~m} / \mathrm{min}$, v odvisnosti od vrednosti $Q$ : a) $3 \mathrm{~mm}$, b) $5 \mathrm{~mm}$, c) $8 \mathrm{~mm}$, d) $20 \mathrm{~mm}$

- Tapping operations were carried out using the M5 and M6 taps on the AISI 304 austenitic stainless steel. It was specified that an increase of the depth of cut for each cutting feed $(Q)$ directly affected the cutting torque. The $Q$ value affecting the tool life was determined.

\section{REFERENCES}

${ }^{1}$ N. Kahraman, B. Gülenç, H. Akça, Mechanical properties of welding of weldment on low carbon steel welded to austenitic stainless steel by arc welding method, Jour. Fac. Eng. Arch. Gazi Univ., 17 (2002) 2, 75-85

${ }^{2}$ H. E. Yeyen, I. Korkut, Y. Turgut, I. Çiftçi, The effects of cutting speed and feed rate on cutting forces and surface roughness in machining of AISI 303 austenitic stainless steel, $5^{\text {th }}$ International Advanced Technologies Symposium, Karabük, Turkey, 2009, 1284-1288

${ }^{3}$ B. Mills, A. H. Redford, Machinability of Engineering Materials, 1st ed., Springer, Netherlands 1983, 107-108, doi:10.1007/978-94-0096631-4

${ }^{4}$ I. Çiftçi, Machining of austenitic stainless steels using CVD multi-layer coated cemented carbide tools, Tribology International, 39 (2006) 6, 565-569, doi:10.1016/j.triboint.2005.05.005

${ }^{5}$ I. Korkut, M. Kasap, I. Çiftçi, U. Seker, Determination of optimum cutting parameters during machining of AISI 304 austenitic stainless steel, Materials and Design, 25 (2004) 4, 303-305, doi:10.1016/ j.matdes.2003.10.011

${ }^{6}$ http://www.guhring.com.tr/article/archive/1/kilavuz.html

${ }^{7}$ A. E. Reiter, B. Brunner, M. Ante, J. Rechberger, Investigation of several PVD coatings for blind hole tapping in austenitic stainless steel, Surface \& Coatings Technology, 200 (2006), 5532-5541, doi:10.1016/j.surfcoat.2005.07.100

${ }^{8}$ K. Kuo, Experimental investigation of ultrasonic vibration-assisted tapping, Journal of Materials Processing Technology, 192 (2007), 306-311, doi:10.1016/j.jmatprotec.2007.04.033

${ }^{9}$ T. Cao, J. W. Sutherland, Investigation of thread tapping load characteristics through mechanistics modeling and experimentation, International Journal of Machine Tools \& Manufacture, 42 (2002) 14, 1527-1538, doi:10.1016/S0890-6955(02)00108-6 


\section{G. UZUN, I. KORKUT: THE EFFECTS OF CUTTING CONDITIONS ON THE CUTTING TORQUE ...}

${ }^{10}$ S. C. Veldhuis, G. K. Dosbaeva, G. Benga, Application of ultra-thin fluorine-content lubricating films to reduce tool/workpiece adhesive interaction during thread-cutting operations, International Journal of Machine Tools and Manufacture, 47 (2007) 3-4, 521-528, doi:10.1016/j.ijmachtools.2006.06.003

${ }^{11}$ M. Jin, S. Watanabe, S. Miyake, M. Murakawa, Trial fabrication and cutting performance of c-BN-coated taps, Surface and Coatings Technology, 133 (2000), 443-447, doi:10.1016/S0257-8972(00) 00926-9

${ }^{12}$ E. J. A. Armarego, M. N. P. Chen, Predictive cutting models for the forces and torque in machine tapping with straight flute taps, Cirp Annals-Manufacturing Technology, 51 (2002) 1, 75-78, doi:10.1016/ S0007-8506(07)61469-3

${ }^{13}$ A. P. S. Dogra, S. G. Kapoor, R. E. Devor, Mechanistic model for tapping process with emphasis on process faults and hole geometry, Journal of Manufacturing Science and Engineering-Transactions Of The ASME, 124 (2002) 1, 18-25, doi:10.1115/1.1430237
${ }^{14}$ http://www.azimtic.com/hizmetlerimiz.html

${ }^{15}$ B. Balcı, AISI 304 Östenitik paslanmaz çelik malzemenin işlenmesinde yüzey pürüzlülüğünün incelenmesi, Bilim Uzmanlığı Tezi, Karabük Üniversitesi Fen Bilimleri Enstitüsü Makine Eğitimi, Karabük 2008

${ }^{16} \mathrm{G}$. Uzun, I. Korkut, The effect of cryogenic treatment on tapping, The International Journal of Advanced Manufacturing Technology, 67 (2013) 1-4, 857-864, doi:10.1007/s00170-012-4529-x

${ }^{17}$ G. Uzun, I. Korkut, Kılavuz ile vida açma işlemine kesme yönteminin ve kesme parametrelerinin etkileri, 3. Ulusal Talaşlı İmalat Sempozyumu, Ankara, Türkiye 2012

${ }^{18}$ Y. Kayir, The effect of hole diameter on cutting forces for tapping on an AA5083 alloy, Jour. Fac. Eng. Arch. Gazi Univ., 25 (2010) 4, 671-679

${ }^{19}$ M. Günay, Investigation of the effects on screw thread of infeed angle during external threading, Gazi University Journal of Science, 24 (2011) 1, 153-160 